\title{
УДК 1
}

DOI: $10.33184 / \mathrm{ksnf} 2021-2021-11-24.22$

\author{
Горбачев С.Б. \\ кандидат политических наук, \\ доцент кафедры философии и культурологии \\ Башкирского государственного университета \\ (2. Уфа, Россия)
}

\section{Почему евразийцы разочаровались в Европе}

Аннотация: Статья посвящена анализу субъективных мотиваций евразийцев первой волны. Используя конкретные примеры, автор показывает, что в отличие от своих идейных предшественников (славянофилов) евразийцы, будучи в эмиграции гораздо ближе знакомыми с европейскими реалиями, имели не только теоретические, но и практические (субъективные) основания для формирования своей позиции, которая выразилась в том числе в разочаровании в европейской цивилизации и культуре.

Ключевые слова: евразийство, славянофилы, евразийцы, Европа, РоссияЕвразия, культура, цивилизация.

$$
\begin{array}{r}
\text { S. Gorbachev } \\
\text { Candidate of political sciences, } \\
\text { Associate Professor of the Department of Philosophy and Cultural Studies } \\
\text { Bashkir State University } \\
\text { (Ufa, Russia) }
\end{array}
$$

\section{Whyt he Eurasians were disappointed in Europe}

Abstract: The article is devoted to the analysis of the subjective motivations of the Eurasians of the first wave. Using specific examples, the author shows that, unlike their ideological predecessors (Slavophiles), the Eurasians, being in exile much more familiar with European realities, had not only theoretical, but also practical (subjective) grounds for the formation of their position, which was expressed in including disillusionment with European civilization and culture.

Keywords: Eurasianism, Slavophiles, Eurasians, Europe, Russia-Eurasia, culture, civilization.

Классическое евразийство возникло в среде русской эмиграции первой волны, заявив о себе выпуском сборника «Исход к востоку. Предчувствия и свершения. Утверждение евразийцев» (София, август 1921 года). Он включил в себя работы четырех авторов: П.Н. Савицкого, П.П. Сувчинского, Г.В. Флоровского, Н.С. Трубецкого. Позднее к ним присоединились Л.П. Карсавин, Н.Н. Алексеев, С.Я. Эфрон и др. В основе евразийской парадигмы лежали четыре идеи: 1) утверждение особых путей развития России как Евразийской цивилизации; 2) идея культуры как симфонической личности; 3) обоснование идеалов на началах православной веры; 4) учение об идеократическом государстве. 
Главной идеей, с которой и начинается евразийское течение, является утверждение, что Россия-Евразия есть особая цивилизация, с особым историческим путем и своей миссией [1, с. 313]. Нельзя сказать, чтобы эта идея была в то время совершенно новаторской. Сходные мысли высказывали и славянофилы, а наиболее четко сформулировал Н.Я. Данилевский («Россия и Европа. Взгляд на культурные и политические отношения Славянского мира к Германо-Романскому», 1869). Однако по очень многим принципиальным моментам евразийцы со славянофилами расходились (например, о роли тюркского компонента в российской культуре). В контексте данной статьи необходимо отметить их разницу в восприятии Европы (и Запада в целом). Славянофилы, отмечая самобытность России, в целом довольно лояльно относились к Европе, особенно к ее прошлому. Евразийцы относились к Европе, к ее стратегии в отношении России весьма негативно: ««война смыла белила и румяна гуманной романо-германской цивилизации, и теперь потомки древних галлов и германцев показали миру свой истинный лик, - лик хищного зверя, жадно лязгающего зубами» [6, с. 49]. Тому есть не только объективные, но и субъективные, связанные с реалиями их собственной эмигрантской судьбы причины.

Славянофилы, принадлежа (в большинстве своем) к привилегированному, обеспеченному классу - дворянству, никогда лично не испытывали какого-либо ущемления со стороны Европы и европейцев. При этом они отмечали таковое в отношении к России в целом. Поводом к написанию Н.Я. Данилевским своего фундаментального труда послужило событие, известное сейчас только узким специалистам. В 1864 году Пруссия и Австрия напали на Данию, отторгнув у нее Шлезвиг и Голштейн. Европейское общественное мнение отреагировало довольно вяло. В 1853 году начинается война России с Турцией, причем повод к этой войне был гораздо более серьезен, а Россия действовала исключительно с позиций тогдашнего международного права. В Европе происходит взрыв общественного негодования, под воздействием которого большинство европейских держав объявляют войну России (Крымская война). Налицо, т.о., «вешание двумя весами», как говорит Данилевский, или «политика двойных стандартов», как говорят теперь. Совершив краткий исторический экскурс, Данилевский убеждается, что в большинстве случаев европейское общественное мнение, правительства настроены по отношению к России негативно. Его вывод: «Европа на признает нас своими. Она видит в России нечто ей чуждое, а вместе с тем такое, что не может служить для нее простым материалом, который можно бы формировать и обделывать по образу и подобию своему... Европа видит поэтому в Руси не чуждое только, но и враждебное начало». [4, с. 57]. Однако можно заметить, что лично для Данилевского этот вывод был чисто теоретическим, на себе он враждебность Европы не ощущал.

Иное дело - евразийцы, и вообще эмиграция первой волны. Приехав в Европу уже не как туристы, потеряв после революции свое состояние (или изначально его не имея), пытаясь не дать что-то Европе, а получить (поддержку, сочувствие, работу) они столкнулись в лучшем случае с холодным равнодушием, почувствовав себя людьми «второго сорта». Так, например, во Франции русские 
эмигранты, не принявшие французское гражданство, были ограничены в возможности перемещения, получения легальной работы - как отмечает И.Л. Солоневич, «чертежи знаменитого парохода «Нормандия» были нелегально, то есть противозаконно, сделаны русской группой инженера Юркевича... Но деньги получили, конечно, французские владельцы русских белых рабов» [5, с. 322]. Логично, что испытав на себе подобное отношение, евразийцы относились к Европе более негативно, чем славянофилы. В этом, в том числе, заключаются субъективные основания классического евразийства.

Разочарование в Европе, европейской культуре оказало, по-видимому, большое влияние на формулирование краткого, но очень емкого определения свободы в евразийстве: «познай самого себя и будь самим собой». Одновременно это утверждение можно считать и определением смысла жизни как для отдельного человека, так и для народа. И первейшим условием выполнения данной максимы является суверенитет как отдельного человека, так и народа, выражающийся в суверенитете государства [2, с. 471; 3, с. 7].

С разработчиками теории локальных цивилизаций - Н.Я.Данилевским, О.Шпенглером, А.Дж.Тойнби, - евразийцев роднит признание плюрализма цивилизаций, но гораздо яснее у них выделяется понятие цели - зачем этот плюрализм нужен, почему необходимо выйти из сферы влияния западной (европейской) цивилизации. Необходимо, как уже было отмечено выше, познать самого себя и быть самим собой. Самопознание является необходимым условием существования личности, идет ли речь о человеке или о народе (который познает себя через самопознание отдельных личностей). И именно государство должно создавать необходимые условия для такого самопознания, давать гарантии народу, что его цель будет достигнута («гарантийное государство» - по Н.Н. Алексееву).

\section{Литература}

1. Горбачев С.Б. Картина мироустройства в евразийстве // Философия в современном мире: сборник научных докладов Международной научнопрактической конференции, посвященной 25-летию семинара «Проблема обоснования знания» и 70-летнему юбилею профессора Кудряшева Александра Федоровича / отв. ред. Г.Г. Салихов. Ч. 1. Уфа: РИЦ БашГУ, 2017. С. 313-315.

2. Горбачев С.Б. Проблема суверенитета государства в современном мире // Евразийский юридический журнал. 2020. № 1 (140). С. 471-473.

3. Горбачев С.Б., Вахитов Р.Р. О событиях в Белоруссии: трансформация общества на фоне геополитики // О вечном и преходящем: сборник научных статей. Выпуск 11 / Отв. ред Р.Х. Лукманова. Уфа: РИЦ БашГУ, 2020. С. 6-10.

4. Данилевский Н.Я. Россия и Европа. Взгляд на культурные и политические отношения Славянского мира к Германо-Романскому. М.: Эксмо, 2003. 640 с.

5. Солоневич И.Л. Народная монархия. М.: Эксмо, 2003. 608 с.

6. Трубецкой Н.С. «Русская проблема»// Россия между Европой и Азией: Евразийский соблазн. Антология. М.: Наука, 1993. С. 48-59. 